\title{
Mineral deficiency predisposes occurrence of retention of placenta in crossbred
}

\author{
S. K. Sheetal, S. K. Choudhary and D. Sengupta
}

Department of Animal Reproduction, Gynaecology and Obstetrics, Bihar Veterinary College, Patna, Bihar, India. Corresponding author: S. K. Sheetal, e-mail: sksheetalmuz@gmail.com, SKC: 51skc16@gmail.com, DS: dip96sen@gmail.com

Received: 10-09-2014, Revised: 17-11-2014, Accepted: 21-11-2014, Published online: 29-12-2014

doi: 10.14202/vetworld.2014.1140-1143. How to cite this article: Sheetal SK, Choudhary SK, Sengupta D (2014) Mineral deficiency predisposes occurrence of retention of placenta in crossbred, Veterinary World 7(12): 1140-1143.

\begin{abstract}
Aim: The present study was carried out to investigate the relationship between blood serum concentrations of macro and micro minerals and development of retention of placenta (ROP) in crossbred cattle.

Materials and Methods: The present study was carried out at Instructional Livestock Farm, Bihar Veterinary College and local Khatals in and around Patna. A total of 20 crossbred cattle ( $\mathrm{n}=10$ with normal expulsion of the placenta as control and $\mathrm{n}=10$ with ROP) were selected in the present study. Blood samples were collected from these animals and serum was separated and stored in the deep freezer at $-20^{\circ} \mathrm{C}$ till further analysis. The estimation of serum macro-minerals $(\mathrm{Ca}, \mathrm{P}, \mathrm{Ca} / \mathrm{P}$ ratio) was done by Span diagnostic Kits (Surat, India) and trace minerals or micro-minerals ( $\mathrm{Zn}, \mathrm{Cu}$, and $\mathrm{Fe}$ ) were analyzed by atomic absorption spectrophotometer (Perkin Elmer AAS 220). Mean values were compared between both the groups at $0 \mathrm{~h}$ (at parturition) and $12 \mathrm{~h}$ after parturition.
\end{abstract}

Results: The mean values of serum calcium and zinc were found significantly lower in cattle having ROP than control at both $0 \mathrm{~h}$ and $12 \mathrm{~h}$ after parturition. The mean values of serum $\mathrm{Ca}$ and $\mathrm{P}$ ratio obtained at 0 hour were significantly lower in ROP groups as compared to control groups and non-significant at $12 \mathrm{~h}$. The mean values of serum inorganic phosphorus, copper and iron was found non-significantly lower in ROP cases as compared to control.

Conclusions: Macro and micro mineral deficiency such as calcium, iron, zinc and copper in blood serum may be predisposing factor for the occurrence of retention of placenta in crossbred cattle.

Keywords: cattle, macro and micro-mineral profiles, parturition, retention of placenta.

\section{Introduction}

Retained fetal membrane is one of the most common disorders affecting reproduction of dairy cattle [1]. It has direct adverse effect on milk production and future fertility of animals. It may result from a number of factors, such as abortion, forced labor, delayed gestation, early parturition, uterine atony, infections, and seasonal and hormonal disorders. In addition, it is well-known that deficiencies of some vitamins and minerals induce or predispose animals to retention of placenta [2].

The physiological delivery of the placenta after parturition requires adequate and regular uterine contractions. Inadequate secretions of prostaglandin F2 $\alpha$, oxytocin and serum $\mathrm{Ca}$ concentration, which maintain adequate contraction of the uterus, may cause retention of placenta (ROP), increase the risk of dystocia and delay the involution of the uterus [3]. Some researchers [4] reported that a low serum Ca concentration plays an important role in the development of ROP in cows, whereas others $[5,6]$ found that the $\mathrm{Ca}$ concentration was at the physiological level, indicating that $\mathrm{Ca}$ has virtually no role in the development of ROP. $\mathrm{Ca}$ and $\mathrm{Zn}$ levels in cows with retained placenta

Copyright: The authors. This article is an open access article licensed under the terms of the Creative Commons Attributin License (http:// creative commons.org/licenses/by/2.0) which permits unrestricted use, distribution and reproduction in any medium, provided the work is properly cited. were significantly lower [7], whereas other [8] documented that the copper deficiency increased the incidence of retained placenta in cows.

The objective of this study was to investigate the relationship between blood serum concentrations of $\mathrm{Ca}, \mathrm{P}, \mathrm{Ca} / \mathrm{P}$ ratio, $\mathrm{Zn}, \mathrm{Cu}$ and $\mathrm{Fe}$ and the development of ROP in crossbred cattle. Estimation of macro and micro-mineral profiles at parturition are also of great diagnostic importance. These parameters will be helpful for predicting its occurrence of ROP, moreover prophylactic measures could be instituted for its prevention.

\section{Materials and Methods}

\section{Ethical approval}

The present investigation was carried out after the approval of the Institutional Animal Ethics Committee.

\section{Selection and maintenance of the animals}

In the present study, crossbred cattle reared under uniform manage mental conditions were selected from Instructional Livestock Farm, Bihar Veterinary College and local Khatals in and around Patna. Altogether 20 crossbred cattle ( $\mathrm{n}=10$ with normal expulsion of the placenta as control and $n=10$ with ROP) were selected in the present study.

\section{Collection of blood sample}

Adequate care and necessary steps were taken up to prevent any untoward stress to the animals. 
Approximately, $15 \mathrm{ml}$ blood samples were collected from ROP and control crossbred cattle $1^{\text {st }}$ at the time of parturition $(0 \mathrm{~h})$ and $2^{\text {nd }}$ at $12 \mathrm{~h}$ after parturition and serum was separated and kept in $10 \mathrm{ml}$ vial. The serum was stored in a deep freezer at $-20^{\circ} \mathrm{C}$ till further analysis. The estimation of serum calcium, serum inorganic phosphorus (macro-minerals) was done by using Span diagnostic Kits (Surat). Trace minerals or micro-minerals viz. Zinc, Copper and Iron were analyzed by atomic absorption spectrophotometer (Perkin Elmer AAS 220).

\section{Statistical analysis}

The mean and standard errors were calculated. The t-test was used to compare the differences in means between groups if any, using standard statistical procedure [9].

\section{Results and Discussion}

The serum calcium $(\mathrm{mg} / \mathrm{dl})$ levels obtained at ' 0 ' $\mathrm{h}$ (at parturition) in ROP and control groups were $7.66 \pm 0.33$ and $9.43 \pm 0.39$, respectively. The corresponding values of serum calcium $(\mathrm{mg} / \mathrm{dl})$ at $12 \mathrm{~h}$ after parturition were $7.49 \pm 0.28$ and $9.32 \pm 0.26$, respectively (Table-1). The level of serum calcium was found significantly $(p<0.01)$ lower in ROP cases when compared to control cases. During the transition period, approximately 3 weeks prior to calving until 3 weeks post-calving, immune function is weakened, and dairy cows have a decreased capacity to fight disease [10]. Factors suggested to be responsible for this immune-suppression include oxidative stress, non-esterified fatty acids, ketones, negative energy balance, and calcium status $[10,11]$. There was lower calcium [12] and total estrogen [13] levels in cows with retained foetal membranes (RFM) compared with normal released placenta. The hormonal profile showed a significant $(p<0.05)$ higher levels of progesterone $(\mathrm{P} 4)$ and cortisol, and significantly $(\mathrm{p}<0.01)$ lower level of estradiol 17- $\beta$ in cows with RFM [12]. Reduction in the level of progesterone at parturition might allow the activity of enzymes that are necessary for the separation of placental membranes [14]. The lower level of calcium in cows with RFM might be due to excessive mobilization of calcium to the fetus during the last stages of pregnancy resulting in less availability to uterine tissue [15]. This decreased level of serum calcium might have caused atony of uterus resulting in RFM [16]. However, prepartum calcium supplementation prevents RFM mainly improving health condition and enhancing myometrial sensitivity [17].

The levels of serum inorganic phosphorus $(\mathrm{mg} / \mathrm{dl})$ obtained at ' 0 ' $\mathrm{h}$ after parturition in ROP and control groups were $4.44 \pm 0.24$ and $4.58 \pm 0.22$, respectively. The corresponding values of serum Inorganic phosphorus $(\mathrm{mg} / \mathrm{dl})$ at $12^{\text {th }} \mathrm{h}$ after parturition was $4.32 \pm 0.28$ and $4.46 \pm 0.26$ respectively (Table- 1 ). The level of serum Inorganic phosphorus was found non-significantly lower in ROP cases when compared to control cases. Ray et al. [18] reported low serum inorganic phosphorus levels in cows with RFM. Low phosphorus level during the pre-calving and post-calving periods predispose the dam to retain fetal membranes [19]. This may also be attributed to decreased contraction of uterine muscles due to low phosphorus levels.

The serum $\mathrm{Ca}$ and P ratio obtained at ' 0 ' $\mathrm{h}$ (at parturition) in ROP and control groups were $1.77 \pm 0.12$ and $2.08 \pm 0.08$, respectively. The corresponding values of serum $\mathrm{Ca}$ and $\mathrm{P}$ ratio at $12 \mathrm{~h}$ after parturition were $1.81 \pm 0.15$ and $2.16 \pm 0.15$, respectively (Table 1 ). The mean values of serum $\mathrm{Ca}$ and $\mathrm{P}$ ratio obtained at ' 0 ' $\mathrm{h}$ were significantly $(\mathrm{p}<0.05)$ lower in ROP groups as compared to control groups and non-significantly lower at $12 \mathrm{~h}$. Ray et al. [18] also reported lower Ca and $\mathrm{P}$ ratio in ROP cows as compared to non-ROP cases. Lower $\mathrm{Ca}$ and $\mathrm{P}$ ratio may also lead to lower/ poor uterine contractions, which might be the cause of ROP in crossbred cows.

The mean values of serum zinc $(\mu \mathrm{g} / \mathrm{ml})$ obtained at ' 0 ' $\mathrm{h}$ (at parturition) in ROP and control groups were $1.27 \pm 0.07$ and $1.49 \pm 0.07$ respectively. The corresponding values of serum zinc $(\mu \mathrm{g} / \mathrm{ml})$ at $12 \mathrm{~h}$ after parturition were $1.24 \pm 0.06$ and $1.45 \pm 0.07$ respectively (Table- 1 ). A significantly $(p<0.05)$ lower levels of serum zinc were found in ROP as compared to control crossbred cattle. Hashem and Amer [12] also reported that cows with retained placenta revealed a significant $(p<0.01)$ decrease in serum zinc $(0.34 \pm 0.20 \mathrm{mg} / 100 \mathrm{ml})$ level than non-RFM i.e. $(0.71 \pm 0.15 \mathrm{mg} / 100 \mathrm{ml})$. Zinc is required to maintain epithelial tissue integrity and for keratin formation which provide a physiological barrier to infection [20,21] and $\mathrm{Zn}$ can impact immune status via a role in cell proliferation. Cells deficient in

Table-1: Macro and Micro-minerals profiles in ROP and non-ROP crossbred cattle.

\begin{tabular}{|c|c|c|c|c|}
\hline \multirow[t]{2}{*}{ Parameters } & \multicolumn{2}{|c|}{ Mean \pm SE (0 h) } & \multicolumn{2}{|c|}{ Mean \pm SE (12 h) } \\
\hline & ROP & Non-ROP & ROP & Non-ROP \\
\hline Calcium (mg/dl)** & $7.66^{a} \pm 0.33$ & $9.43^{b} \pm 0.39$ & $7.49^{a} \pm 0.28$ & $9.32^{b} \pm 0.26$ \\
\hline Phosphorus (mg/dl)* & $4.44^{\mathrm{a}} \pm 0.24$ & $4.58^{\mathrm{a}} \pm 0.22$ & $4.32^{\mathrm{a}} \pm 0.28$ & $4.46^{\mathrm{a}} \pm 0.26$ \\
\hline $\mathrm{Ca} / \mathrm{P}$ ratio* & $1.77^{\mathrm{a}} \pm 0.12$ & $2.08^{b} \pm 0.08$ & $1.81^{a} \pm 0.15$ & $2.16^{a} \pm 0.15$ \\
\hline $\mathrm{Zn}(\mu \mathrm{g} / \mathrm{ml})^{*}$ & $1.27^{\mathrm{a}} \pm 0.07$ & $1.49^{b} \pm 0.07$ & $1.24^{\mathrm{a}} \pm 0.06$ & $1.45^{\mathrm{b}} \pm 0.07$ \\
\hline $\mathrm{Cu}(\mu \mathrm{g} / \mathrm{ml}) *$ & $1.32^{\mathrm{a}} \pm 0.10$ & $1.40^{\mathrm{a}} \pm 0.11$ & $1.30^{\mathrm{a}} \pm 0.08$ & $1.37^{\mathrm{a}} \pm 0.09$ \\
\hline $\mathrm{Fe}(\mu \mathrm{g} / \mathrm{ml}) *$ & $1.40^{\mathrm{a}} \pm 0.08$ & $1.61^{\mathrm{a}} \pm 0.07$ & $1.37^{\mathrm{a}} \pm 0.08$ & $1.57^{\mathrm{a}} \pm 0.07$ \\
\hline
\end{tabular}

$\mathrm{ROP}=$ Retention of placenta, $\mathrm{SE}=$ Standard error, Means with different superscripts $(\mathrm{a}, \mathrm{b})$ row-wise vary significantly $(* * \mathrm{p}<0.01, * \mathrm{p}<0.05)$ 
Zn have decreased ability to proliferate, and immune cell response requires rapid cell proliferation $[22,23]$. Zinc has a critical role in the repair and maintenance of the uterine lining following parturition and speeding return to normal reproductive function and estrus. Lower levels of zinc increase the chances of retention of fetal membranes in cows.

The mean values of serum Copper $(\mu \mathrm{g} / \mathrm{ml})$ obtained at ' 0 ' $\mathrm{h}$ (at parturition) in ROP and control groups were $1.32 \pm 0.10$ and $1.40 \pm 0.11$, respectively. The corresponding values of serum Copper $(\mu \mathrm{g} / \mathrm{ml})$ at $12 \mathrm{~h}$ after parturition were $1.30 \pm 0.08$ and $1.37 \pm 0.09$, respectively (Table-1). A non-significantly lower level of serum copper was found in ROP as compared to control crossbred cattle. Present findings corroborated with the reports of Samal and Mishra [8] in cows. Ahmed et al. [24] also reported lower level of serum copper in buffaloes with RFM. Lower level of serum copper increases the cases of retention of fetal membranes and necrosis of the placenta in cows. It was found that organic trace minerals supplementation pre-partum had a positive effect on parturition and reduction placental expulsion period in dairy cows [25].

The mean values of serum iron $(\mu \mathrm{g} / \mathrm{ml})$ obtained at ' 0 'h (at parturition) in ROP and control groups were $1.40 \pm 0.08$ and $1.61 \pm 0.07$ respectively. The corresponding values of serum Iron $(\mu \mathrm{g} / \mathrm{ml})$ at $12 \mathrm{~h}$ after parturition were $1.37 \pm 0.08$ and $1.57 \pm 0.07$, respectively (Table-1). The mean values of serum iron $(\mu \mathrm{g} / \mathrm{ml})$ obtained on two schedules were although statistically non-significant but lower in ROP groups as compared to control groups. The present findings are on the line with those reported by Sivaraman et al. in cows [26] and Ahmed et al. in buffaloes [24]. They reported decreased level of Iron in cows and buffaloes retaining their fetal membranes. Feedstuffs can contain a significant amount of $\mathrm{Fe}$ and therefore most diets would appear to meet $\mathrm{Fe}$ requirements without supplementation [27]. However, if soil contamination is a major source of $\mathrm{Fe}$ in the diet, the $\mathrm{Fe}$ is largely unavailable to the animal [28]. It is due to the presence of Fe chelating agent's ferric form, which is considered less bioavailable than ferrous $\mathrm{Fe}$ [27]. In addition, research suggests $\mathrm{Fe}$ status may decline in late gestation [27]. Minerals are important in the prevention of RFM [29] and other studies have found that additional supplementation of trace minerals can have positive [30] effect on reproductive performance.

\section{Conclusion}

The mean values of serum calcium and zinc were found significantly lower in ROP cases as compared to control cases at both $0 \mathrm{~h}$ (at parturition) and $12 \mathrm{~h}$ after parturition. The mean values of serum inorganic phosphorus, copper and iron was found non-significantly lower in ROP cases as compared to control. The data presented in this study can be used as a baseline to study the serum macro and micro-minerals profile due to ROP and Non-ROP in crossbred cattle and therefore have applications for diagnostic and/or preventive purpose. Therefore, the quantity of the mineral substances should be taken into consideration prior to parturition in the diets of cows.

\section{Authors' Contributions}

SKS carried out the experiment and drafted the final manuscript. SKC designed the experiment, guided during the experiment. DS helped in the analysis of the data and scientifically corrects the manuscript. All authors read and approved the final manuscript.

\section{Acknowledgments}

This article is the part of M. V. Sc. thesis to the Bihar Agriculture University, Sabour, Bhagalpur, Bihar, by the first author. The authors are thankful to Dr. S. Sammantaray, Dr. K. G. Mandal and Dr. P. K. Singh for their unconditional guidance and help in carrying out this research work smoothly. The authors are very much grateful to the Principal, Bihar Veterinary College, Patna, Bihar, India for providing the facilities for conducting this experiment. The authors are also thankful to BAU, Sabour, Bhagalpur, Bihar, India, for providing necessary fund for this study.

\section{Competing of Interests}

The authors declare that they have no competing interests.

\section{References}

1. Stephen, J.L. (2008) A postpartum uterine disease and dairy herd reproductive performance: A review. Vet. J., 176(1): 102-114.

2. Alacam, E. (2002) The Domestic Animals Obstetrics and Infertility.. Medisan Publishing house, Ankara..

3. McDowell, L.R. (1992) Minerals in Animal and Human Nutrition. Academic Press, London.

4. Zhang, C.K., Ye, J.P. and Chen, J.H. (1992) The changes of mineral contents of serum during the dry period and prior to and after calving in dairy cows with retained placenta. Chin. J. Vet. Med., 18: 10-11.

5. Lotthammer, K.H. (1983) Comparative studies of the course of mineral, metabolite, enzyme and hormone levels in blood serum ante partum in dairy cows with and without later retained placenta. Dtsch. Tierarztl. Wochenschr., 90: 427-433.

6. Mutiga, E.R., Mba, I.K., Tsuma, V.T., Karitu, P.T. and Ojiayo, S.O. (1993) Incidence and causes of retained placenta in smallholder dairy herds. Indian Vet. J., 70: 333-336.

7. Akar, Y. and Yildiz, H. (2005) Concentration of some minerals in cows with retained placenta and abortion. Turk. J. Vet. Anim. Sci., 29, 1157-1162.

8. Samal, L. and Mishra, C. (2010) Significance of macro and micro minerals for reproductive health of farm animals. Proceeding XXVI Annual Convention of ISSAR and Int. Symposium On "Biotechnologies for Optimization of Reproductive Efficiency of Farm and Companian Animals to Improve Global Food Security and Human Health" held at Pantnagar, India. p77.

9. Snedecor, G.W. and Cochran, W.G. (1994) Statistical Methods. $8^{\text {th }}$ ed. The Iowa State Univ. Press. Ames., Iowa, U.S.A.

10. Waldron, M.R. (2010) Impact of metabolic and oxidative 
stressors on periparturient immune function and health. Penn State Dairy Cattle Nutrition Workshop. p33-39.

11. Sordillo, L.M. (2009) Current concepts on immunity and mastitis. WCDS Adv. Dairy Technol., 21: 111-119.

12. Hashem, M.A. and Amer, H.A. (2008) Hormonal and biochemical anomalies in dairy cows affected by retained fetal membranes. Int J Vet Med., Available from: http://www.priory.com/vet.htm dated-05.11.2014.

13. Hartmann, D., Honnens, A., Piechotta, M., Lüttgenau, J., Niemann, H., Rath, D. and Bollwein, H. (2013) Effects of a protracted induction of parturition on the incidence of retained placenta and assessment of uterine artery blood flow as a measure of placental maturation in cattle. Theriogenology, 80(3): 176-184.

14. Maj, J.G., Kankofer, M. (1997) Activity of $72-\mathrm{kDa}$ and 92- $\mathrm{kDa}$ matrix metalloproteinases in placental tissues of cows with and without retained fetal membranes. Placenta, 18(8): 683-687.

15. Mohanty, Ke., Mohanty, B.N., Ray, S.K.H. and Mohanty, D.N. (1994) Levels of glucose, calcium and alkaline phosphatase in blood with relation to retention of placenta in bovines. Indian Vet. Med. J., 13: 64-65.

16. Arthur, G.H., Noakes, D.E. and Pearson, H. (1992) Veterinary Reproduction and Obstetrics. 6th ed. Bailliere Tindall, London. p283-293.

17. Sosa G.A. and Nasr M.T. (1995) Control of placental retention and its influence on subsequent fertility in Friesian cows. The $7^{\text {th }}$ Ann. Cong. Egypt. Soc. Anim. Reprod. Fert., Cairo. p162-170.

18. Ray, S.K.H., Dash, H.D., Mohanty, D.N., Das, S., Bisnoi, P.C. and Barik, A.K. (2004) Studies on certain hematological and biochemical constituents in cows with retained fetal membranes. Indian J. Anim. Reprod., 25(2): 128-130.

19. Tillard, E., Humblot, P., Faye, B., Lecomte, P., Dohoo, I. and Bocquier, F. (2008) Postcalving factors affecting conceptionrisk in Holstein dairy cows in tropical and sub-tropical conditions. Theriogenology, 69(4): 443-457.

20. Socha, M.T., Tomlinson, D.J. and Ward, T.L. (2005) Benefits of improving trace mineral status of dairy replacement heifers. Proceedings of the 2005 Four-State Dairy Nutrition and Management Conference. June 15 and $16^{\text {th }}$. Dubuque, Iowa. p31-43.

21. O'Rourke, D. (2009) Nutrition and udder health in dairy cows. A review. Ir. Vet. J., 62 Suppl 4: 15-20.

22. Spears, J.W. and Weiss, W.P. (2008) Role of antioxidants and trace elements in health and immunity of transition dairy cows. Vet. J., 176(1): 70-76.

23. Forsberg, N.E. (2010) Nutritional regulation of innate and mucosal immunity. Proceedings of the 2010 Penn State Dairy Cattle Nutrition Workshop. November 10, 11. Grantville, PA. p25-32.

24. Ahmed, W.M., Abd El Hameed, A.R., El Khadrawy, H.H. and Hanafi, E.M. (2009) Investigations on retained placenta in Egyptian buffaloes. Global Vet., 3(2): 120-124.

25. Khanthusaeng, V., Navanukraw, C., Aiumlamai, S., Nilsri, P. and Suwannasan, C. (2014) Effect of organic trace minerals supplement during pre and postpartum dairy cows on parturition, incidence of retained foetal membranes, first estrus and ovulation. Thai J. Anim. Sci., 2: 35-38.

26. Sivaraman, T., Shanmugasundsaram, S., Arunachalam, S. and Sivakumar, T. (2003) Blood profile of constituents associated with production diseases in Jersey crossbred cows. Indian J. Anim. Sci., 73: 44-47.

27. Weiss, W.P., Pinos-Rodriguez, J.M. and Socha, M.T. (2010) Effects of feeding supplemental organic iron to late gestation and early lactation cows. J. Dairy Sci., 93(5): 2153-2160.

28. Hansen, S.L. and Spears, J.W. (2009) Bioaccessibility of iron from soil is increased by silage fermentation. J. Dairy Sci., 92(6): 2896-2905.

29. Wilde, D. (2006) Influence of macro and micro minerals in the peri-parturient period on fertility in dairy cattle. Anim. Reprod. Sci., 96(3-4): 240-249.

30. Sales, J.N.S., Pereira, R.V.V., Bicalho, R.C. and Baruselli, P.S. (2011) Effect of injectable copper, selenium, zinc and manganese on the pregnancy rate of crossbred heifers Bos indicus x Bos Taurus synchronized for timed embryo transfer. Livest. Sci., 142: 59-62. 